\title{
Impact of FDI in Insurance Sector
}

\author{
S. Nithya, G. Vinayagamoorthi, S. Josephin Arulmozhi
}

\begin{abstract}
One of the most hanging traits during the last many years is the amazing increase of FDI in the international economic system panorama. This excellent improvement of FDI in 1990 around the globe make FDI a important and critical phase of development technique in each created and creating nations and preparations are configuration with a selected cease intention to animate internal streams. FDI offers a win-win situation to the host and the nations of origin. The international locations are straightforwardly inspired by way of welcoming FDI, in mild of the fact that they advantage a great deal from such kind of task. As a rule FDI alludes to capital inflows from abroad that put sources into the era limit of the economic system and are normally favoured over other sort of outer fund due to the fact they're non-obligation making non-risky and their earnings rely upon the execution of the undertakings financed by the economic professionals. FDIinflow encourages the creating countries to created sincere, expansive and compelling association situation for task troubles and, assembles human and institutional abilties to execute the identical. The safety phase is of massive importance to each developing economic system; in includes the sparing propensity, which thusly produces lengthy haul investible assets for basis constructing. This present day Paper's locations are to explore the Indian Insurance part, to realize blessings of expanded outdoor direct undertaking restrain in protection section, to recognize the Government arrangement with respect to protection department in India, to understand Issues in FDI in Insurance Sector.
\end{abstract}

Keywords : FDI, insurance sector in india, inflow, outflow, investment limits.

\section{INTRODUCTION}

Even after the liberalization of the coverage quarter, the public region coverage organizations have endured to dominate the coverage marketplace, taking part in over 90 consistent with cent of the market proportion. FDI is the procedure whereby residents of one $\mathrm{u}$. S . A - Accumulate ownership of assets for the motive of controlling the manufacturing, distribution and sports of company in another country.A important role played by the coverage area is to mobilize national savings and channelize them into investment in exceptional sectors of the financial system. FDI in insurance would boom the penetration of insurancein India; FDI can meet India's long-term capital requirements to fund the

Revised Manuscript Received on September 25, 2019

* Correspondence Author

S.Nithya, Ph.D. Research Scholar (Part-Time), Department of Commerce, Alagappa University, Karaikudi.

Dr. G. Vinayagamoorthi, Assistant Professor, Department of Commerce, Alagappa University, Karaikudi.

S.Josephin Arulmozhi, Ph.D. Research Scholar (Full-Time), Department of Commerce, Alagappa University, Karaikudi. building of infrastructures. Insurance area has the functionality of raising long-time period capital from the loads, as it is the most effective road wherein people put in money for as long as 30 years even more. An increase in FDI in insurance might circuitously be a boon for the Indian financial system. The coverage sector has also been rapid developing with good sized sales growth in the non-life coverage market. Over the years, FDI inflow in the united states is growing. However, India has extremely good ability for absorbing greater drift of FDI in the approaching years. The position of overseas direct funding in the gift international is noteworthy. It acts as the lifeblood in the growth of the growing countries. Thewave of liberalization and globalization sweepings across insurance regulatory and improvement authority (IRDA) is in favour of an increase in overseas equity capital in the insurance joint ventures. The insurance markets in the arena.

\section{Objectives}

1. To find out benefits of elevated overseas direct funding restriction in insurance region.

2. To studythe Government coverage regarding insurance zone in India.

3. To know Issues in FDI in Insurance Sector.

\section{HISTORY OF INSURANCE}

A contract of insurance may be defined as a settlement wherein, one character, called the 'insurer', undertakes, in return for the agreed attention, known as the 'top class' to pay to another individual, referred to as 'assured', a sum of cash or its equal on the taking place of a precise event. The intention of all insurance is to make provisions against risks which beset human existence and dealings. Those who are seeking it enterprise to avert failures from themselves with the aid of transferring viable losses at the shoulders of others who're inclined for pecuniary consideration, to take hazard thereof, and within the case of life guarantee, theyendeavor to assure to those depending on them a positive provision in case of their death, or to provide a fund out of which their lenders may be glad. In India, insurance has a deep-rooted history. It finances point out in the writings of Manu(manusmrithi), Yagnavalkya(Dharmasastra) (Arthasastra). 
The writing talks in terms of pooling of resources that should be re-distributed in times of calamities such as fire,floods, epidemics and famine. This turned into likely a precursor to cutting-edge day insurance. Ancient Indian records has preserved the earliest strains of coverage in the form of marine change loans and vendors' contracts. Insurance in India has evolved over tome heavily drawing from other international locations, England especially.

\section{The British Period}

1818 noticed the introduction of lifestyles insurance business in India with the established order of the oriental life insurance enterprise in Calcutta. This organization but failed in 1834 . 1870 noticed the enactment of the British coverage Act. This technology, but, changed into ruled by way of foreign coverage workplaces which did proper enterprise in India. The Indian life warranty agencies act, 1912 became the first statutory degree to modify life business. In 1928, the Indian insurance agencies act changed into enacted to enabled the authorities to gather statistical information about each life and non-existence enterprise transacted in India by way of Indian and overseas insurers along with provident coverage societies. In 1938, with a view to shielding the hobby of the coverage public, the earlier legislation was consolidated and amended by the coverage act, 1938 with complete provisions for effective control over the activities of insurers.

\section{The Nationalized Period}

The coverage change act of 1950 abolished major companies. However, there had been a large quantity of insurance corporations and the extent of competition became high. There had been also allegations of unfair trade practices. The government of India, therefore, determined to nationalize insurance business. In nationalized era an ordinance handed on 19thJanuary, 1956 nationalizing the life coverage quarter and Life Insurance Corporation came into life in the identical yr. LIC absorbed 154 Indian, sixteen non-Indian insurers as also 75 provident societies-245 Indian and overseas insurers in all. The LIC had monopoly till the past due 90s whilst the coverage area become reopened to the personal area. Due to new liberalization, privatization and globalization, the insurance sector turned into reopened to the non-public quarter.

\section{The Liberalized Period}

The insurance regulatory and Development Authority become constituted as an self sustaining body to alter and increase the coverage industry. The IRDA spread out the marketplace in august 2000 with the invitation for utility for registrations. The invoice permits foreign equity stake in domesticprivate insurance corporations to maximum of $26 \%$ of the full paid-up capital and seeks to offer statutory repute to the coverage regulator. Foreign businesses have been allowed possession of up to $26 \%$. In December, 2000, the subsidiaries of the widespread coverage organization of India had been restructured as impartial organizations and at the equal time GIC was transformed into a national reinsurer. Parliament exceeded a bill de-linking the 4 subsidiaries from GIC in July, 2002.

\section{Government Policy regarding Insurance Sector in India}

In order to do away with the paradox that prevails on what is Foreign Direct Investment and what is Foreign Institutional Investment, I endorse to comply with the global practice and lay down a huge precept that where an investor has a stake of $10 \%$ or much less in a employer, it is going to be treated as FDI. A committee will be constituted a to observe the software of the precept and to work out the info expeditiously'Pursuant to the statement, a committee changed into constituted by using Government of India endorsed that-

1.Foreign investment of $10 \%$ or more via eligible devices made in an Indian indexed corporation would be treated as FDI. All current overseas investments beneath threshold restriction made under the FDI path shall but, continue to be dealt with as FDI

.2.An investor may be allowed to invest below the ten $\%$ threshold and this can be handled as FDIsubject to circumstance that the FDI stake is raised to $10 \%$ or past within one $\mathrm{yr}$ from the date of the first purchase. The responsibility to achieve this will fall on the agency. If the stake is not raised to $10 \%$ or above, then the funding shall be treated as portfolio funding 3.In case an existing FDI falls to a level under $10 \%$, it can maintain to be treated as FDI without an duty to restore it to $10 \%$ or more, as the original funding was an FDI.4.In a selected organization, an investor can keep the investments either underneath the FDI route or under the FII path, however no longer each. Insurance being integral element of the monetary area performs a sizeable role in India's financial system. Apart from protecting towards mortality, belongings and casualty dangers and providing a protection internet for people and corporations in city and rural areas, the insurance zone encourages saving and gives lengthy-term funds for infrastructure development and different long gestation tasks of the state. The development of the insurance quarter in India is important to assist its endured economic transformation. This millennium has 
visible insurance come a complete circle in a adventure extending to almost 2 hundred years. The procedure or re-beginning of the sector had started in the early1990s and the remaining decade and greater has visible it been opened up appreciably. In 1993, the government set up a committee beneath the chairmanship of R.N.Malhotra, former governor of RBI, to recommend hints for reforms in the coverage sector. The objectives were to supplement the reforms initiated in the financial zone. The committee submitted its document in 1994wherein, amongst different things, it recommended that the personal quarter be permitted to go into the insurance enterprise. They stated that overseas agencies are allowed to enter by floating Indian companies, ideally a joint task with Indian companions. The IRDA opened up the market in August 2000 with the invitation for utility for registrations. Foreign organizations had been allowed ownership of up to $26 \%$. The Authority has the energy to body law under section 114-A of the Insurance Act, 1938 and has from 2000 onwards framed numerous regulations protection of policyholders interests. Today there are 28 general coverage businesses (Non-lifestyles) such as the Export Credit Guarantee Corporation (ECGC) and Agriculture Insurance Corporation of India, 24 lifestyles insurance organizations which have installation operations inside the lifestyles segment put up commencing up of the sector 20 are in joint undertaking with foreign partners. Of the twenty two private insurers who have started out operations in the non-lifestyles segments, 18 are in collaboration with overseas companions.

\section{BENEFITS OF INCREASES IN FOREIGN DIRECT INVESTMENT LIMIT IN INSURANCE SECTOR}

The cupboard committee on financial affairs headed by using Prime Minister Narendra Modi has authorized the restriction of foreign direct investment in coverage zone to forty nine percent from the present 26 percent. The cabinet has cleared the FDI limit in insurance corporations thru FIPB path which necessitates the management manipulate with the Indian promoters. This turned into a long due reform which the Modi government has undertaken and is clearly bond to gain the insurance region. Let's look at the six key advantages of extended foreign direct investment restriction in insurance area:-

\section{Increased insurance penetration}

With the population of extra than a hundred cores, India requires insurance extra than any other country. However, the coverage penetration within the US. Is only around 3 percent of our gross domestic product with recognize to over-all rates underwritten annually. This is a long way less in comparison to Japan which has an insurance penetration of extra than 10 percentages. Increased FDI restrict will enhance the present companies and also will permit the brand new players to are available, thereby permitting more humans to buy life cover.

\section{Level playing field}

With the increase in foreign direct investment to 49 percentage, the coverage groups gets the extent gambling subject. So a ways the nation owned Life Corporation of India controls around 70 percent of the coverage marketplace.

\section{Job creation}

With more money coming in, the insurance organizations could be capable of create greater jobs to meet their objectives of venturing into under insured markets through improved infrastructure, better operation and greater manpower.

\section{Favorable to the pension sector}

If the pension invoice is passed inside the parliament then the overseas direct investment within the pension finances may also be raised to 49 percent. This is because the pension fund regulatory improvement Bill hyperlinks the FDI limit within the pension zone to the coverage region.

\section{Consumer friendly}

The give up beneficiary of this amendment might be common men. With extra gamers on this sector, there is bound to be stringent competition leading to competitive quotes, improved services and better claim agreement ratio.

\section{ISSUES IN FDI IN INSURANCE SECTOR}

\section{1) Efficiency of the companies with FDI}

The beginning up of this sector for non-public participation in 1999, allowed the personal agencies to have foreign equity up to 26 according to cent. Following this up 12 non-public area organizations have entered the existence coverage business. Apart from the HDFC, which has foreign equity of $18.6 \%$, all of the different private organizations have foreign equity of 26 per cent. In general insurance 8 non-public organizations have entered, 6 of that have overseas fairness of 26 consistent with cent. Among the non-public players in standard coverage, Reliance and Cholamandalam does not have any overseas fairness. The mixture lossof the private existence insurers amounted to Rs. 38633 lakhs in evaluation to the Rs. 9620 crores surplus (after tax) earned through the LIC. In standard insurance, 4 out of the eight personal insures suffered losses in 2002-03, with the Reliance, a organization without a foreign equity, emerging as the most profitable participant. In reality the 6 private gamers with foreign fairness made an 
mixture lack of Rs. 294 lakhs. On the other hand the public quarter insurers in general insurance made aggregate after tax earnings of Rs. 62570 lakhs.

\section{2) Credibility of foreign companies}

The argument that foreign agencies shall deliver in more expertise and professionalism into the prevailing gadget is arguable after the latest incidents of the worldwide financial disaster wherein firms like AIG, Lehman Brothers and Goldman sachs collapsed. Earlier too, the Prudential Financial Services (ICICI's partner in India) confronted an enquiry with the aid of the securities and coverage regulators in the U.S primarily based upon allegations of getting falsified files and cast signatures and asking their clients to sign clean forms. This turned into after it made a charge of $\$ 2.6$ billion to settle a category-actionlawsuit attacking incorrect insurance income practices in 1997 and a \$ 65 million greenback nice from nation coverage regulators in 1996. AMP closed its existence operations for brand new commercial enterprise in June 2003. Royal Sun Alliance also close down their profitable organizations in 2002. A recent report through Mercer Oliver Wyman, a consultancy, located that European life insurance organizations are quick of capital via a whopping60 billion Euros. According to the Mercer Oliver Wyman Report the German, Swiss, French and British insurers be afflicted by intense capital inadequacy, that is a end result of venture volatile funding in equity and debt contraptions in the beyond. Hence FDI in insurance in India might divulge our monetary markets to the dubious and speculative sports of the foreign insurance businesses at a time while the virtues of regulating such activities are being mentioned in the advanced countries.

\section{3) Greater channelization of saving to insurance} One of the maximum critical responsibilities played by the insurance area is to mobilize countrywide saving and channelize them into investments in different sectors of the economy. However, no huge exchange seems to have passed off as a long way as mobilizing financial savings by way of the insurance region isconcerned even after the liberalization of the insurance area in 1999. Therefore the personal or overseas participation has now not been able to achieve the purpose.

\section{4) Flow of funds to infrastructure}

The number one aim of lifestyles coverage is set mobilizing the savings for the development of the economic system in long time funding in social and infrastructure sectors. The equal imaginative and prescient became argued for the hole up of coverage market could allow large

flow of price range into infrastructure. But greater than fifty percentage of the policies they sell are ULIPS wherein the investments cross into the equity markets.

\section{ADVANTAGES OF FDI IN INSURANCE SECTOR}

\section{1) Capital for Expansion}

FDI has the capacity to satisfy India's long term capital requirements to fund the building of infrastructures that's important for the development of the $\mathrm{u}$. $\mathrm{S}$.. Infrastructure has been the most important aspect which has restricted the progress of the Indian economic system. Insurance quarter has the functionality of elevating long term capital from the loads as it is the only street in which humans installed money for as long as 30 years even greater. An increase in FDI in insurance could not directly be a boon for the Indian economic system, the investment not withstanding but by means of making extra human beings invest in long term finances to fuel the growth of the Indian economy.

\section{2) Wider Scope for Growth}

FDI in insurance might boom the penetration of insurance in India, wherein the penetration of insurance is abysmally low with insurance premium at approximately three $\%$ of GDP towards about $8 \%$ global average. This would be higher via advertising and marketing attempt by means of MNCs, better product innovation, client education and many others.

\section{3) Moving Towards Global Practices}

India's insurance marketplace lags in the back of other economies in the baseline degree of coverage penetration. At most effective three.1\%, India is nicely behind the 12. Five $\%$ for the United Kingdom, $10.5 \%$ for japan, $10.3 \%$ for Korea and nine.2\% for america. Currently, FDI represents only Rs. 827 crore of the Rs.3179 crores capitalizations of private existence coverage organizations.

\section{4) Provide Customers with Competitive Products,} More Options and Better Service Levels

Opening the FDI inside the insurance area would be proper for the clients, in a variety of methods. Increasing FDI will effect on a lot of industries in a fantastic.

\section{CONCLUSION}

Many international research have anticipated that the coverage region in India can grow through over one hundred twenty five in line with cent in the subsequent ten years. 
In fact, India has been diagnosed as one of the fastest growing insurance markets. The contemporary coverage is attempting to inspire joint ventures coverage sector which will enhance the home insurer's growth on this location. However; there may be also the hazard that some foreign insurers will no longer be interested by making an investment except they have got $100 \%$ ownership and that the current coverage will prevent them from selecting India as an Insurance destination. With this, a plethora of enterprise possibilities in India has been thrown open to the foreign investors. In existence coverage enterprise, India is ranked 10thamong the 88 international locations for which records are posted by Swiss Re. India has visible an increase in its FDI in 2012, at a time whilst the aforesaid restriction were no longer even permitted-a signal that suggests India is ready to be certainly one of the popular locations for overseas buyers inside the insurance zone. Increased role of overseas capital can also cause the opportunity of exposing the economic system to the vulnerabilities of the global marketplace through manner of in all likelihood inheritance of unsound stability sheets and financial fitness of the foreign partners via joint ventures and subsidiary routes Flight of capital outside the country and also endangering the interest of the policy holders. The present international financial situation, any similarly hike in FDI at this juncture won't be within the hobby of the Indian coverage zone, wherein the commonplace guy too might no longer stand to gain via coverage, particularly as a means of social protection.

\section{REFERENCES}

1. Evans Sam, Sharma Shashwat, Doshi Sanjay,(2014)Higher FDI in Indian Insurance Sector-a buzz for the Industry,Retrieved from http:/www.kpmg.com/Global/en/Issues

andInsights/articlespublications/Documents/fdi-cap-increase-for-indian-i nsurers-v2.pdf

2. Kapoor Harsha,(2013)FDI in Insurance for a better future,Retrieved fromhttp://www.avizare.com/assets/FDI\%20in\%20Insurance\%20\%20F or\%20a\%20Better\%20Future.pdf

3. Mishra Vinay. V, Bhatnagar Harshida, (2014)Foreign Direct Investment in Insurance Sector in India, Retrieved fromwww.academia.edu

4. Rhea Jinhal, (2014)benefitsof FDI in insurance sector in India,Retrievedfrom

https://storify.com/rheajind/benefits-of-fdi-in-insurance-sector-in-india 